\title{
Characterization of the sheep industry in the medium northern region of Mato Grosso, Brazil
}

\section{Caracterização da ovinocultura na região médio-norte de Mato Grosso, Brasil}

\author{
Camila Eckstein, ${ }^{\star *}$ Felipe Cecconello Bento, ${ }^{* *}$ Raphael Castro Mourão, ${ }^{* * *}$ Luciano Bastos Lopes, ${ }^{* * * \star}$ \\ Helen Fernanda Barros Gomes, ${ }^{* *}$ Valéria Spyridion Moustacas, ${ }^{* * * *}$ Renato de Lima Santos ${ }^{* * * *}$
}

\begin{abstract}
Resumo
Nas últimas décadas o mercado brasileiro de carne ovina aumentou substancialmente, e o estado de Mato Grosso apresentou a maior taxa de crescimento do Brasil, apesar da falta de informações sobre os sistemas de produção nesta região. Este estudo teve como objetivo caracterizar os sistemas de produção de ovinos da região meio-norte do Mato Grosso, utilizando um questionário com perguntas qualitativas e quantitativas. Dentre as 40 propriedades avaliadas foram predominantes (82,5\%; 33/40) rebanhos com menos de 100 animais, com exploração semi-intensiva, voltada para a produção de carne. A ovinocultura foi citada como atividade econômica secundária em 92,5\% (37/40) dos rebanhos e, em 60,0\% (24/40) das propriedades, os animais eram mantidos apenas para consumo familiar. O manejo sanitário deficiente resultou na ocorrência de diversas doenças, sendo os casos de miíases os mais citados $(65,0 \% ; 26 / 40)$. A ovinocultura possui grande potencial para o desenvolvimento em Mato Grosso. No entanto, a atividade ainda é negligenciada em muitos aspectos, incluindo a saúde animal.
\end{abstract}

Palavras-chave: ovinocultura, perfil dos rebanhos, saúde animal.

\begin{abstract}
In recent decades, the Brazilian market for sheep meat has increased substantially, and the State of Mato Grosso had the highest growth rate in Brazil. However, information about ovine production systems in this region is lacking. This study aimed to characterize productive systems of sheep in the medium northern region of Mato Grosso, by application of qualitative and quantitative questionnaires. Among 40 properties evaluated, herds there were predominately with fewer than 100 animals (82.5\%, 33/40), with semi-intensive exploration focused on meat production. Livestock sheep was a secondary economic activity in $92.5 \%(37 / 40)$ of farms, and sheep were kept only for family consumption in 60.0\% (24/40). Poor health management resulted in the occurrence of various diseases, and myiasis was the most frequently cited disease $(65.0 \%, 26 / 40)$. Sheep farming has a great potential for development in Mato Grosso. However, the activity is neglected in many ways, including animal health.
\end{abstract}

Keywords: Sheep breeding, livestock profile, animal health.

\section{Introduction}

Sheep farming has great potential to contribute to regional development, especially in areas with great demand for sheep meat such as Midwest and Southeast regions of Brazil. The market for sheep had a significant increase, resulting in an increase of $161 \%$ in imports by Brazil in 2013 when compared to the previous year (Raineri et al. 2014). In spite of this market expansion, there are marked contrasts between states in regard to sheep production.

Currently, sheep farming is migrating towards the central regions of Brazil, especially the states of Mato Grosso, Acre, Rondônia, and Pará (Jesus Júnior et al. 2010). Between 1976 and 2010, Mato Grosso had the highest growth rate of sheep farming (above 50\%) among all Brazilian states (Hermuche et al. 2013). Despite this expansion, Brazilian flocks are commonly characterized by extensive farming, with low investment levels, and deficient sanitary conditions (Santos et al. 2011), compromising animal health and, consequently, productivity (Alencar et al. 2010).

Considering that sheep farming is a new economic activity in less traditional areas, actions to improve production and expand markets are increasingly necessary. Thus, characterization of production systems is highly relevant for strategic purposes. Therefore, the present study aimed to characterize sheep flocks in the medium northern region of Mato Grosso.

*Recebido em 30 de julho de 2016 e aceito em 24 de agosto de 2017.

**Universidade Federal de Mato Grosso, Departamento de Zootecnia, Sinop, Mato Grosso, Brasil.

***Instituto Federal de Educação, Ciência e Tecnologia de Mato Grosso, Sorriso, Mato Grosso, Brasil.

****Empresa Brasileira de Pesquisa Agropecuária - Embrapa Agrossilvipastoril, Sinop, Mato Grosso, Brasil.

*****Universidade Federal de Minas Gerais, Escola de Veterinária, Departamento de Clínica e Cirurgia Veterinária, Belo Horizonte, Minas gerais, Brasil. Corresponding author: rsantosufmg@gmail.com. 


\section{Material and methods}

This study was conducted between July 2012 and December 2013 based on information from 40 sheep herds located in the medium northern region of Mato Grosso. Regional designation was based on the IMEA (Instituto Mato Grossense de Economia Agropecuária, 2010) classification. The study included the following municipalities: Sinop, Vera, Cláudia, Santa Carmen, Ipiranga do Norte, and Itaúba. Probabilistic sampling was conducted due to unavailability of property records by the state official agencies.

Production systems were characterized regarding their production and sanitary conditions by applying a questionnaire adapted from Yorinori (2001). The questionnaire included structural characteristics of property, socioeconomic status of the farmer, and technical characteristics of production units.
Table 1: Origin of rams and reproductive management in sheep herds of the mid northern region of the State of Mato Grosso

\begin{tabular}{llcc}
\hline Parameter & Stratum & N/Total & Frequency (\%) \\
\hline \multirow{3}{*}{ Rams origin $^{\text {a }}$} & Bought & $30 / 40$ & 75.0 \\
& Exchanged & $10 / 40$ & 25.0 \\
& Borrowed & $4 / 40$ & 10.0 \\
\hline \multirow{3}{*}{ Time of rams stay on property } & One year & $5 / 40$ & 12.5 \\
& Two years & $17 / 40$ & 42.5 \\
& Three years & $1 / 40$ & 2.5 \\
& Continuous & $6 / 40$ & 15.0 \\
& Not answer & $11 / 40$ & 27.5 \\
\hline \multirow{3}{*}{ Reproduction } & Natural mount & $37 / 40$ & 92.5 \\
& Controlled mount & $3 / 40$ & 7.5 \\
& Artificial insemination & $0 / 40$ & 0.0 \\
\hline
\end{tabular}

${ }^{a}$ The property can use more than one strategy for acquisition of rams.
Exploration strategies were classified according to the management practices, as follows: extensive (when animals were kept exclusively on pasture and without any nutritional supplementation throughout the year), semi-intensive (animals received some nutritional supplementation during some periods of the year), and intensive system (animals were kept in confinement at all time). A database was generated using the Excel software, and frequencies of several parameters were obtained.

\section{Results}

The average number of animals per property was $211.6 \pm 778.4$ (mean \pm standard deviation), ranging from 7 to 5,000 animals per herd. In $42.5 \%(17 / 40)$ of the farms there were fewer than 50 animals; $40.0 \%(16 / 40)$ had up to 100 animals; $12.5 \%(5 / 40)$ had up to 500 animals; and only $5.0 \%(2 / 40)$ of herds had more than 500 sheep.

Santa Inês was the most frequent breed $(67.5 \% ; 27 / 40)$, followed by crossbred with $22.5 \%(9 / 40)$, and Dorper corresponding to $7.5 \%(3 / 40)$. Ile de France, Texel, Lacaune, Suffolk, and Morada Nova breeds were identified, but these later breeds were reported in lower frequencies. Santa Inês, Dorper, Texel, and Sulfolk (breeds specialized for meat production) were the basis for most of the crossbred herds. All studied herds were from national origin, being $95.0 \%$ of rams $(38 / 40)$ and $90.0 \%$ of ewes $(36 / 40)$ originally from the State of Mato Grosso. The remaining sheep were from South and Southeast regions of Brazil. Table 1 summarizes the origin of rams and reproductive management.

The production systems were characterized as extensive in two farms $(5.0 \%)$, as semi-intensive in $90.0 \%(36 / 40)$, and as intensive in two farms $(5.0 \%)$. Meat was most important product for $97.5 \%$ (39/40) of farms, whereas one farm raised sheep for genetic improvement purposes.

The average age of farmers was over 51 years, and only $20.5 \%$ of them had a college degree. Table 2 summarizes characteristics of farmers, including age, and educational level, and market barriers mentioned by them.

Total time dedicated by farmers to sheep farming ranged from a few months to 21 years. Although more than half of them $(57.5 \%$; 23/40) had been in this business for less than 5 years. The

Table 2: Characteristics of sheep farmers (age and educational level), and commercialization barriers cited by farmers in the mid northern region of the State of Mato Grosso

\begin{tabular}{llcc}
\hline Parameter & Stratum & N/Total & Frequency (\%) \\
\hline \multirow{3}{*}{ Age rate } & Between 20 and 30 years & $1 / 40$ & 2.5 \\
& Between 31 and 40 years & $6 / 40$ & 15.0 \\
& Between 41 and 50 years & $12 / 40$ & 30.0 \\
\hline \multirow{3}{*}{ Education } & Above 51 years & $21 / 40$ & 52.5 \\
& Elementary school & $18 / 39$ & 46.1 \\
& High school & $13 / 39$ & 33.3 \\
& Higher education & $8 / 39$ & 20.5 \\
& Did not answer the question & $1 / 40$ & 2.5 \\
\hline \multirow{3}{*}{$\begin{array}{l}\text { Commercialization } \\
\text { barriers }\end{array}$} & Unaware of barriers or did not & $22 / 40$ & 55.0 \\
& answer & & 15.0 \\
& Purchaser lack or low consumer & $6 / 40$ & 12.5 \\
& Slaughterhouses distance & $5 / 40$ & 7.5 \\
& Production costs/ Sell price & $3 / 40$ & 5.0 \\
& Affirm does not exist barriers & $2 / 40$ & 5.0 \\
& Chain organization of labor & $2 / 40$ & \\
& absence & &
\end{tabular}


average total area of the properties was 416 hectares (ha), and the average area destined for sheep production was 16.1 ha (Table 3 ).

In $60.0 \%$ (24/40) of the farms, sheep production aimed exclusively to provide for familiar consumption, whereas commercialization of meat destined to local markets, i.e. within the municipality corresponded to $35.0 \%(14 / 40)$ of farms, and other markets corresponded to $5.0 \%$ (2/40). Most farmers sold meat directly to the final consumers $(85.7 \%)$. Only $7.5 \%(3 / 40)$ of producers had sheep farming as their primarily activity. No employees were hired exclusively to manage the ovine herds in $32.5 \%$ (13/40) of the farms.

Most farms had predominantly cultivated pastures (32/40; $80.0 \%)$, whereas $20 \%(8 / 40)$ of farms had native pastures. In $57.5 \%(23 / 40)$ of the farms, pastures were split to allow for separation of different animal categories. In $22.5 \%(9 / 40)$ of farms different types of forage were cropped, and in $37.5 \%(15 / 40)$ supplementary feed practices were applied (Table 3). Animal supplementation with concentrate was reported in $90.0 \%(36 / 40)$ of farms, with $61.1 \%(22 / 36)$ produced within the farm, $25.0 \%$ (9/36) used commercial rations, $11.1 \%(4 / 36)$ used corn, and 5.5\% (2/36) adopted other strategies. In $90.0 \%$ (36/40) of farms, mineral supplements were used.

No health certificate of any kind was required for purchasing animals by $75.0 \%$ of farmers, and $52.5 \%$ (21/40) did not have technical assistance. Only one farmer $(2.5 \%)$ reported regularly performing diagnosis of brucellosis, leptospirosis, and tuberculosis. In addition, $35.0 \%$ (14/40) reported regular vaccination for clostridiosis $(25.0 \%$; 10/40), brucellosis $(7.5 \%$; $3 / 40)$, foot and mouth disease $(5.0 \% ; 2 / 40)$, and pneumonia $(2.5 \% ; 1 / 40)$

In $95.0 \%(38 / 40)$ of the farms at least one frequent disease was reported. The most frequently cited diseases included: myiasis $(65.0 \%)$, lymphadenitis $(47.5 \%)$, pododermatitis $(47.5 \%)$, mastitis $(45.0 \%)$, oestrosis $(37.5 \%)$, abortion $(30.0 \%)$, keratoconjunctivitis $(27.5 \%)$, pneumonia $(22.5 \%)$, ectoparasites $(20.0 \%)$, diarrhea $(12.5 \%)$, arthritis $(12.5 \%)$, contagious ecthyma $(10.0 \%)$, and worms (2.5\%).

For controlling endoparasites, $97.5 \%$ (39/40) of farms used anthelmintic, but only $15.0 \%$ (6/40) assessed the parasite load for determining the schedule for treatment. Importantly, 65.0\% (26/40) adopted rotation
Table 4: Sanitary strategies in sheep flocks of the mid northern region of the State of Mato Grosso

\begin{tabular}{|c|c|c|c|}
\hline Parameter & Stratum & N/ Total & Frequency $(\%)$ \\
\hline \multirow{5}{*}{$\begin{array}{l}\text { Hoof trimming } \\
\text { frequency }\end{array}$} & Bimonthly & $4 / 22$ & 18.2 \\
\hline & Biannual & $3 / 22$ & 13.6 \\
\hline & Annual & $2 / 22$ & 9.1 \\
\hline & Four months & $1 / 22$ & 4.5 \\
\hline & When considered necessary & $12 / 22$ & 54.5 \\
\hline \multirow{3}{*}{$\begin{array}{l}\text { Sheep share } \\
\text { premisses with } \\
\text { other species }\end{array}$} & Bovine & $20 / 24$ & 83.3 \\
\hline & Equine & $3 / 24$ & 12.5 \\
\hline & Poultry & $1 / 24$ & 4.1 \\
\hline \multirow{5}{*}{$\begin{array}{l}\text { Contact with other } \\
\text { species }^{a}\end{array}$} & Dogs & $29 / 32$ & 90.6 \\
\hline & Cattle and horses & $13 / 32$ & 40.6 \\
\hline & Poultry & $12 / 32$ & 37.5 \\
\hline & Goats & $1 / 32$ & 3.1 \\
\hline & Wild animals & $1 / 32$ & 3.1 \\
\hline
\end{tabular}

${ }^{a}$ More than one species per farm may have had contact with sheep. of anthelmintic drugs without any technical criteria. Hoof trimming was reported in $55.0 \%$ (22/40) of farms (Table 4). Sheep shared their area and/or premises with other farm animals in $60.0 \%$ $(24 / 40)$ of farms, and had sporadic contact with other species in $80.0 \%(32 / 40)$ of farms (Table 4$)$.

Table 3: Total area, area destined to sheep production, and feed strategies employed by heep farmers of the mid northern region of the State of Mato Grosso

\begin{tabular}{llcc}
\hline Parameter & Stratum & N/ Total & Frequency (\%) \\
\hline \multirow{3}{*}{ Total area of properties } & Less than 10 ha & $7 / 40$ & 17.5 \\
& Between 10 and 50 ha & $11 / 40$ & 27.5 \\
& Between 50 and 100 ha & $2 / 40$ & 5.0 \\
& Between 100 and 500 ha & $10 / 40$ & 25.0 \\
& Above 500 ha & $9 / 40$ & 22.5 \\
& Did not answer the question & $1 / 40$ & 2.5 \\
\hline \multirow{3}{*}{ Area destined for sheep production } & Less or equal to 10 ha & $25 / 40$ & 62.5 \\
& Between 10 and 50 ha & $12 / 40$ & 30.0 \\
& Above 50 ha & $2 / 40$ & 5.0 \\
& Did not answer the question & $1 / 40$ & 2.5 \\
\hline \multirow{3}{*}{ Grazing strategy } & Continuous & $26 / 40$ & 65.0 \\
& Pasture rotation & $13 / 40$ & 32.5 \\
& Did not answer the question & $1 / 40$ & 2.5 \\
\hline Supplementary feed practices a & Silage & $9 / 15$ & 60.0 \\
& Hay & $5 / 15$ & 33.3 \\
& Sugar cane & $4 / 15$ & 26.7 \\
& Grass stocking piles & $2 / 15$ & 13.3 \\
\hline
\end{tabular}

a More than one supplementation strategy can be adopted on the property. 


\section{Discussion}

Despite the average of 211.6 of animals per herd observed in this study, most herds (82.5\%) had fewer than 100 animals. The predominance of small flocks is associated with the fact that in most farms production was destined for familiar consumption only. Moreover, sheep farming was often considered a secondary economic activity, which can be a determinant factor for low levels of investment, as identified by Raineri et al. (2015) in São Paulo State. However, the economic potential of sheep husbandry has been previously demonstrated in the State of Minas Gerais, where it is the main business for $44.5 \%$ of the farmers (Almeida et al. 2010). In contrast to the extensive production systems largely adopted in Brazil (Almeida et al. 2010), in Mato Grosso, there was a predominance of semi-intensive systems.

Genetic adaptation to tropical conditions is a key aspect for development of the sheep industry in Brazil. In Mato Grosso, there is a predominance of Santa Inês and crossbreed animals, which favor productivity under tropical conditions, considering the adaptability of these animals (Costa et al. 2008; McManus et al. 2013). In contrast, a negative aspect is the low domestic consumption. In a study about meat consumption in the municipality of Sorriso, Mato Grosso, Pereira et al. (2013) reported that bovine meat is the first choice by consumers, corresponding to $32.5 \%$, followed by poultry $(22.2 \%)$, swine $(21.0 \%)$, fish (14.3\%), and other (10.1\%), including sheep, goat, and water buffalo. In addition, this study demonstrated that meat is often sold directly to the final consumers. Apparently the absence of specialized slaughterhouses is a limitation factor for expansion of ovine meat production in Mato Grosso. This study also demonstrated the absence of commercial exploration of ovine skin, which has a potential to improve the economic potential of this activity.

The predominant use of locally bred animals observed in this study reflects the low investment in genetics (Perez-Hernandez et al. 2011). While in the southern part of Brazil the average time dedicated to sheep farming by producers was 36.9 years (Viana and Waquil 2013), in Pernambuco, located in the northeastern part of the country, this time was inferior than 5 years (Coelho et al. 2011).

Natural breeding was employed in most of the farms in this study (92.5\% of flocks), which results in lower costs, but the lack of herd monitoring may result in significant impairment of the productive potential of the flock (Simplício and Azevedo 2014; Abreu et al.
2003). Indeed, technical assistance was absent in more than half of the flocks (52.5\%), which is similar to previous observations in the State of Pernambuco (Alencar et al. 2010). Abortion rates in sheep are usually low, i,e, between 1 and $2 \%$. Infectious causes of abortion include chlamydiosis, toxoplasmosis, salmonellosis, and brucellosis (Echevarria et al. 2008; OIE 2015). The occurrence of abortion in $30 \%$ of herds in this study requires proper investigation and preventive intervention, although the lack of technical and diagnostic assistance favors dissemination of these diseases.

Guimarães et al. (2011) demonstrated that $43.7 \%$ of animals and $100 \%$ of sheep flocks in the State of Minas Gerais were seropositive for caseous lymphadenitis. In the State of Pernambuco, the occurrence of myiasis, abortion, and diarrhea affected more than $80.0 \%$ of the herds, and abscesses were reported in $92.5 \%$ of the properties (Alencar et al. 2010). Climatic conditions such as high humidity and temperature favor the survival of environmental stages of parasites (Ramos et al. 2004), constituting a possible risk factor for verminosis. Deworming was adopted in $97.5 \%$ of flocks in this study, but the absence of assessment of parasitic loads as criteria for anthelmintic treatment may result in future problems with resistance to antiparasitic drugs. The occurrence of foot pad dermatitis is commonly related to regions of hot and humid weather, particularly during the rainy seasons (October to April in Mato Grosso), and the most efficacious approach to control and treat the disease is hoof trimming (Aguiar et al. 2009). In this study, $47.5 \%$ of the farmers reported the occurrence of this disease, which may be directly correlated to the low frequency of hoof trimming (55.0\% of the properties).

The concomitant sheep breeding associated to other domestic species was identified as a common practice (Costa et al. 2008). Although this management can be a risk factor for some diseases (Coelho et al. 2011), it allows different sources of income throughout the year and dilution of fixed costs of ownership, better use of human capital and best land use (Viana and Waquil 2013).

In the medium northern region of the State of Mato Grosso sheep farming is characterized predominantly by semi-intensive production systems, with meat production for family consumption as the most common goal. The sheep production was not the main activity in most of the properties, which results in low technological level. Health management was often deficient, which was associated with a high incidence of diseases.

\section{Acknowledgements}

To the Mato Grosso Research Foundation (FAPEMAT) for financial support.

\section{References}

ABREU, U.D.; CEZAR, I.M.; TORRES, R.A. Análise bioeconômica da introdução de período de monta em sistemas de produção de rebanhos de cria na região do Brasil Central. Revista Brasileira de Zootecnia, v.32, p.1198-1206, 2003.

AGUIAR, G.M.N.; ASSIS, A.C.O.; SILVA, T.R.; ARAÚJO, J.R.B.; GARINO JUNIOR, F.; SIMÕES, S.V.; RIET-CORREA F. Pododermatite infecciosa em ovinos e caprinos no sertão paraibano. Ciência Animal Brasileira, v. 1, p. 585-590, 2009.
ALENCAR, S.P.; MOTA, R.A.; COELHO, M.C.O.C.; NASCIMENTO, S.A.; ABREU, S.R.O.; CASTRO, R.S. Perfil sanitário dos rebanhos caprinos e ovinos no sertão de pernambucano. Ciência Animal Brasileira, v.11, p.131-140, 2010. ALMEIDA, A.C.; TEIXEIRA, L.M.; DUARTE, E.R.; MORAIS, G.; SILVA, B.C.M.; GERASEEV, L.C. Perfil sanitário dos rebanhos caprinos e ovinos no Norte de Minas Gerais. Comunicata Scientiae, v.1, p.161-166, 2010.

COELHO, M.C.S.C.; SOUZA, V.C.; COELHO, M.I.S.; CUNHA, M.P.; MEDINA, F.T. Aspectos sanitários de rebanhos caprinos e ovinos criados em assentamentos no município de Petrolina-PE. Revista Semiárido de Visu, v. 1, p. 32-40, 2011. 
COSTA, R.G.; ALMEIDA, C.C.; PIMENTA FILHO, E.C.; HOLANDA JUNIOR, E.V.; SANTOS, N.M. Caracterização do sistema de produção caprino e ovino na região semi-árida do estado da Paraíba, Brasil. Archivos de Zootecnia, v. 57, p.195-205, 2008.

ECHEVARRIA, F.A.M.; PINHEIRO, A.C.; RIBEIRO, L.A.O. Sistema de Criação de Ovinos nos Ambientes Ecológicos do Sul do Rio Grande Do Sul. Embrapa Pecuária Sul, Sistemas de Produção 2. 2008. Available from: https:// sistemasdeproducao.cnptia.embrapa.br/FontesHTML/Ovinos/ CriacaoOvinosAmbientesEcologicosSuIRioGrandeSul/saude. htm\#topo. Accessed 10 feb 2016.

GUIMARÃES, A.S.; CARMO, F.B.; HEINEMANN, M.B.; PORTELA, R.W.; MEYER, R.; LAGE, A.P.; SEYFFERT, N.; MIYOSHI, A.; AZEVEDO, V.; GOUVEIA, A.M. High seroprevalence of caseous lymphadenitis identified in slaughterhouse samples as a consequence of deficiencies in sheep farm management in the state of Minas Gerais, Brazil. BMC Veterinary Research, v. 7, p. 68, 2011.

HERMUCHE, P.M.; MARANHÃO, R.L.A.; GUIMARÃES, R.F.; CARVALHO JUNIOR, O.A.; GOMES, R.A.T.; PAIVA, S.R.; MCMANUS, C. Dynamics of sheep production in Brazil. ISPRS International Journal of Geo-Information, v. 2, p. 665-679, 2013.

Instituto Mato-grossense de Economia Aplicada. Mapa de macrorregiões do IMEA. Available from: http://www.imea.com. $\mathrm{br} /$ upload/publicacoes/arquivos/justificativamapa.pdf. Accessed 27/08/2015.

JESUS JÚNIOR, C.; RODRIGUES, L.S.; MORAES, V.E.G. Ovinocaprinocultura de corte: a convivência dos extremos. BNDES Setorial, v. 31, p. 281-320, 2010.

MCMANUS, C.; HERMUCHE, P.; PAIVA, S.R.; MORAES, J.C.F.; MELO, C.B.; MENDES, C. Geographical distribution of sheep breeds in Brazil and their relationship with climatic and environmental factors as risk classification for conservation. Brazilian Journal of Science and Technology, v.1, p.1-15, 2013.

OIE- World Organization for Animal Health. Manual of Diagnostic Tests and Vaccines for Terrestrial Animals 2015. http://www.oie. int/en/international-standard-setting/terrestrial-manual/accessonline/. Accessed 05/02/2016.
PEREIRA, J.S.; METZ, L.; GOFFI, C.G.S.; MOURÃO, R.C. Perfil do mercado consumidor de carne bovina do município de Sorriso, MT. In: VIII CONGRESSO NORDESTINO DE PRODUÇÃO ANIMAL. 2013. Anais... Fortaleza, CE.

PEREZ-HERNÁNDEZ, P.; ARRONIZ, J.V.; MOLINA, H.C.; MARTINEZ, B.C.; RIVERA, B.P.D.; ORTIZ, S.L. Análisis descriptivo de los sistemas de producción con ovinos en el estado de Veracruz, México. Revista Científica, v. 21, n. 04.

RAINERI, C.; NUNES, B.C.; GAMEIRO, A.H. Technological characterization of sheep production systems in Brazil. Animal Science Journal, v. 86, p. 476-485, 2015.

RAINERI, C.; SANTOS, F.F.; GAMEIRO, A.H. Ovinocultura de corte no Brasil: balanço de 2013 e perspectivas para 2014. Revista Educação Continuada em Medicina Veterinária e Zootecnia, v.12, p.12-17, 2014.

RAMOS, C.I.; BELLATO, V.; SOUZA, A.P.; AVILA, V.S.; COUTINHO, G.C.; DALAGNOL, A. Epidemiologia das helmintoses gastrintestinais de ovinos no Planalto Catarinense. Revista Ciência Rural, v. 34, p.1889-1895, 2004.

SANTOS, T.C.P.; ALFARO, C.E.P.; FIGUEIREDO, S.M. Aspectos sanitários e de manejo em criações de caprinos e ovinos na microrregião de Patos, região semi-árida da Paraíba. Ciência Animal Brasileira, v.12, p. 206-212, 2011.

SIMPLÍCIO, A.A.; AZEVEDO HC. Manejo Reprodutivo: Foco na taxa de reprodução. In: Embrapa Tabuleiros Costeiros-Artigo em anais de congresso (ALICE). Acta Veterinária Brasilica, v. 8, p. 320-331, 2014.

VIANA, J.G.A.; WAQUIL, P.D. Comparative analysis of economic and institutional configuration of the sheep production in south of Brazil and Uruguay. Livestock Research for Rural Development, v. 25, p.7, 2013.

YORINORI, E.H. Características dos sistemas de produção de pequenos ruminantes e prevalências da artrite - encefalite caprina (CAE) e maedi - visna (MV) ovina, nas regiões norte e nordeste de Minas Gerais, 2000. 2001. 98 f. Dissertação (Mestrado em Medicina veterinária Preventiva e Epidemiologia) -Escola de Veterinária, Universidade Federal de Minas Gerais, Belo Horizonte 2001. 